\title{
Peran Antioksidan Karotenoid Penangkal Radikal Bebas Penyebab Berbagai Penyakit
}

\author{
Yostan A. Labola ${ }^{*}$, Dhanang Puspita ${ }^{2}$
}

${ }^{1}$ Graduate School of Biology, Satya Wacana Christian University, Diponegoro St. 52-60, Salatiga 50711

${ }^{2}$ Faculty Of Medicine And Health Sciences, Satya Wacana Christian University, Kartini St. 11 A, Salatiga 50711

*email: yostan87@gmail.com

\section{Abstrak :}

Keberagaman lingkungan bumi menjadi sumber kesehatan yang luas. Salah satu senyawa biokatif alami dari sumber alam adalah karotenoid. Karotenoid telah disarankan kebermanfaatannya dibidang kesehatan (farmasi/obat-obatan), pangan (pewarna alami makanan), dan kosmetik. Dalam bidang kesehatan, karotenoid berperan dalam meredam singlet oksigen (1O2) dan radikal bebas lainnya, penyebab stres oksidatif yang berkontribusi terhadap perkembangan berbagai penyakit pada manusia.

Kata kunci : radikal bebas, karotenoid, kesehatan, pewarna alami, kosmetik,

\section{Pendahuluan}

Planet bumi telah diciptakan dengan beraneka ragam tumbuhan, hewan bahkan berbagai jenis mikroorganisme. Ini menjadi sumber kesehatan yang luas bagi manusia. Untuk itu,sangat diperlukan eksplorasi dan evaluasi melalui penelitian-penelitian. Saat ini, beberapa senyawa bioaktif alami telah dilaporkan oleh para peneliti berkhasiat sebagai obat-obatan dengan toksisitas rendah dan bermanfaat sebagai strategi terapuetik berbagai penyakit.

Salah satu contoh senyawa alami yang telah dikonfirmasi potensi dan kebermanfaatannya dibidang kesehatan (farmasi/obat-obatan), pangan (pewarna alami makanan), dan kosmetik adalah senyawa antioksidan alami karotenoid. Karena itu, sangat penting dalam ulasan ini disampaikan peran antioksidan karotenoid dalam kesehatan manusia, terutama peran senyaawa ini dalam menangkal radikal bebas penyebab stress oksidatif yang berkontribusi terhadap perkembangan berbagai penyakit lainnya.

\section{Radikal Bebas}

Para pakar biokimia dan disiplin ilmu terkait menyebut radikal bebas sebagai spesies oksigen reaktif (ROS). Ini karena, yang banyak dipelajari adalah radikal oksigen. Namun radikal bebas dapat berupa turunan karbon $(\mathrm{C})$ dan nitrogen $(\mathrm{N})$.

Radiakal bebas dikatakan sebagai senyawa reaktif (labil) karena electron bagian luarnya tidak berpasangan sehingga berusaha melengkapi dengan menambah dan atau mengurangi elektron untuk mengisi serta mengosongkan lapisan luamya dan bergabung bersama atom yang lain dalam rangka melegkapi lapisan luarnya (Halliwell dan Gutteridge, 2007 ; Bahorun et al., 2006 ; Valko et al., 2004 ; Valko et al., 2007 ; Droge, 2002). 


\section{Penemuan metode baru pemisahan senyawa kiral}

Molecular imprinting polymer (MIP) pertama kali digunakan sebagai fase diam pemisahan kiral pada tahun 1970 oleh Wulff. Keuntungan dari MIP sebagai fase diam pemisahan kiral adalah afinititas dan selektivitas yang tinggi terhadap molekul target. Selain itu, biaya produksi dari MIP juga relatif rendah. Keuntungan ini yang kemudian meningkatkan penggunaan MIP. ${ }^{8}$

Dalam tubuh manusia, radikal bebas adalah molekul yang sangat tidak stabil dan memiliki elektron yang tersedia untuk bereaksi dengan berbagai substrat organik seperti lipid, protein, DNA dan mampu menghasilkan oksidasi makromolekul biologis yang tidak dapat dipulihkan kembali (Stadtman dan Levine, 2000 ; Richter et al., 1988).

Beberapa oksidan dalam biologi yang dapat menyebabkan radikal bebas adalah kelompok molekul oksigen reaktif (ROS) seperti, anion superoksida $\left(\mathrm{O} 2^{*}\right.$-) dan radikal hidroksil $\left({ }^{*} \mathrm{OH}\right)$ serta kelompok non-radikal reaktif, seperti hidrogen peroksida $(\mathrm{H} 2 \mathrm{O} 2)$ atau oksigen singlet (1O2). Pham-Huy et al (2008) mengatakan bahwa oksidan anion superoksida dianggap sebagai molekul yang paling kuat dan merusak. Ini dikarenakan adanya rantai transportasi mitokondria dan sumber fisiologis utama $\left(\mathrm{O}^{*}{ }^{*}\right)$.

\section{Pembentukan Radikal Bebas}

Pembentukan radikal bebas berlangsung terus menerus dalam tubuh manusia melalui metabolism sel, peradangan, nutrisi maupun radiasi sinar- $\gamma$, sinar $x, U V$, bahan kimia pada makanan, obat-obatan dan polusi lingkungan bahkan pola makan. Apabila radikal bebas bereaksi dengan komponen biologis (lipid, protein dan DNA) akan menghasilkan senyawa teroksidasi dan terjadi kerusakan oksidatif (stress oksidatif). Biasanya mekanisme pembentukan reaksi berantai radikal bebas terjadi melalui tiga tahapan reaksi yaitu, inisiasi, propagasi dan terminasi.

Tahapan inisiasi merupakan langkah pertama terciptanya spesies radikal. Secara umum, ini adalah peristiwa pembelahan homolitik yang jarang terjadi karena hambatan energi. Biasanya tahapan ini terbentuk karena pengaruh beberapa hal seperti, suhu tinggi, UV ataupun katalis mengandung logam digunakan sebagai penghalang energi.

Pada tahapan propagasi, bagian 'rantai' dari reaksi berantai. Begitu radikal bebas reaktif dihasilkan, akan menjadi pemicu untuk bereaksi dengan molekul stabil dan membentuk radikal bebas baru. Demikian hal ini terus menerus berlangsung dengan melibatkan abstraksi hidrogen atau penambahan radikal menjadi ikatan rangkap dan menghasilkan banyak radikal bebas. Sementara pada tahapan terminasi, reaksi radikal akan berhenti jika dua radikal saling bereaksi dan menghasilkan suatu spesies non radikal.

\section{Over Radikal Bebas}

Dalam sel, radikal bebas kelompok oksigen reaktif (ROS) berperan sebagai pensinyalan, homeostasis antar sel, pencegah kematian sel terprogram dan induksi gen pertahanan (Rada dan Leto, 2008). Namun, kadar radikal bebas akan meningkat karena tekanan lingkungan, radiasi pengion, paparan sinar UV atau panas (Devasagayam etal., 2004). 
Peningkatan kelompok oksigen reaktif atau radikal bebas lainnya dalam tubuh menyebabkan kerusakan parah pada sel, secara kumulatif adalah stres oksidatif, penyebab berbagai macam penyakit seperti penyakit pada mata (katarak dan retina), pembuluh darah (arteriosclerosis, hipertensi, iskemia, kardiomiopati, gagal jantung), multi-organ (kanker, penuaan, diabetes, inflamasi dan infeksi), otak (Alzheimer, parkinson, hilang ingatan, depresi dan stroke), sendi (reumatik dan radang), paru-paru (asma dan bronchitis), ginjal (glomerulonefritis dan gagal ginjal) dan gangguan pada janin (preeklamsia) (Pham-huy etal., 2008).

\section{Karotenoid}

Secara ilmiah karotenoid merupakan kelompok pigmen isoprenoid yang berasal dari biosintesis terpenoid. Sederhananya, karotenoid didefinisikan sebagai pigmen yang bertanggung jawab atas warna kuning, oranye hingga merah.

Karotenoid diproduksi oleh tanaman, alga, bakteri fotosintetik (Gross, 1991 ; Stahl dan Sies, 2003), beberapa spesies bakteri non-fotosintetik, ragi dan jamur. Manusia dan hewan tidak memproduksi karotenoid tetapi dapat ditemukan pada darah dan jaringan tubuh sebagai asupan dari makanan, buah-buahan dan sayuran. Pada manusia, karotenoid prekursor penting retinol (vitamin A) dan sebagai foto proteksi.

\section{Mekanisme Antioksidan Karotenoid Menetralisir Radikal Bebas}

Antioksidan merupakan senyawa penting yang berperan dalam tubuh manusia sebagai penangkal radikal bebas. Karotenoid tersusun atas senyawa fitokimia antioksidan kompleks penyusun diet sehat yang sangat efisien dalam meredam singlet oksigen (1O2) dan mendeaktivasi radikal bebas lainnya.

Karotenoid menyerap cahaya, melalui serangkaian proses fisika kimia berperan sebagai (foto) proteksi terhadap kenusakan foto-oksidatif. Misalnya, karotenoid ( $\beta$-karoten) telah dilaporkan oleh Christensen (1999) dan Scheer (2003) bahwa tingkat energy triplet karotenoid ini terletak dekat dengan $102(1274 \mathrm{~nm}, 7849 \mathrm{~cm}-1$ atau $93,9 \mathrm{~kJ} / \mathrm{mol}$ vs $1380 \mathrm{~nm}, 7250 \mathrm{~cm}-1$ atau $86,7 \mathrm{~kJ}$ / mol menjadikan $\beta$-karoten sebagai antioksidan alami yang sangat baik. Dengan demikian, proses peredaman singlet oksigen (1O2) terbukti sangat efisien, terutama untuk karotenoid yang memiliki 11 ikatan rangkap terkonjugasi ( $1010 \mathrm{M}-1 \cdot s-1)$ (Husain etal., 1987).

Meskipun perilaku protektif karotenoid ditunjukkan sangat menengah (Fiedor et al., 2001 ; Fiedor et al., 2002), namum secara umum penonaktifan 102 didasarkan pada konversi kelebihan energi untuk memanaskan melalui keadaan triplet paling rendah karotenoid (3karotenoid ${ }^{\star}$ ) (Persamaan 1 dan 2).

$$
\begin{aligned}
& { }^{1} \mathrm{O}_{2}+{ }^{1} \text { Karotenoid } \rightarrow{ }^{3} \mathrm{O}_{2}+{ }^{3} \text { Karotenoid } \ldots \ldots \ldots \ldots . .1 \\
& { }^{3} \text { Karotenoid } * \rightarrow{ }^{1} \text { Karotenoid }+ \text { panas } \ldots \ldots \ldots \ldots \ldots . . .2
\end{aligned}
$$

Sementara untuk mendeaktivasi radikal bebas, ada tiga jenis reaksi utama dari karotenoid yaitu, (a) transfer elektron antara radikal bebas $\left(R^{*}\right)$ dan karotenoid, menghasilkan pembentukan kation radikal karotenoid/karotenoid ${ }^{*}+\left(\right.$ Persamaan 3 ) atau anion radikal karotenoid $/$ karotenoid $^{*}$ (Persamaan 4), formasi (b) adduct radikal (Rkarotenoid*) (Persamaan 5) dan (c) transfer atom hidrogen yang mengarah ke radikal karotenoid netral (karotenoid*) (Persamaan 6) (Edge dan Truscott., 1998 ; El-Agamey et al., 2004). 


$$
\begin{aligned}
R^{*}+\text { Karotenoid } & \rightarrow R^{-}+\text {Karotenoid }^{*+} \ldots \ldots \ldots .3 \\
R^{*}+\text { Karotenoid } & \rightarrow R^{-}+\text {Karotenoid }^{*-} \ldots \ldots \ldots . .4 \\
R^{*}+\text { Karotenoid } & \rightarrow \text { RKarotenoid } \text { Karo }^{*} \ldots \ldots \ldots \ldots \ldots . \\
R^{*}+\text { Karotenoid } & \rightarrow R H+\text { Karotenoid }^{*} \ldots \ldots \ldots \ldots 6
\end{aligned}
$$

Paling mudah memahami karotenoid sebagai antioksidan sebagai penetralisir dengan menyumbang salah satu elektronnya untuk radikal bebas (molekul tidak stabil) yang kemudian menjadi molekul stabil, seperti ditunjukkan Gambar 1.

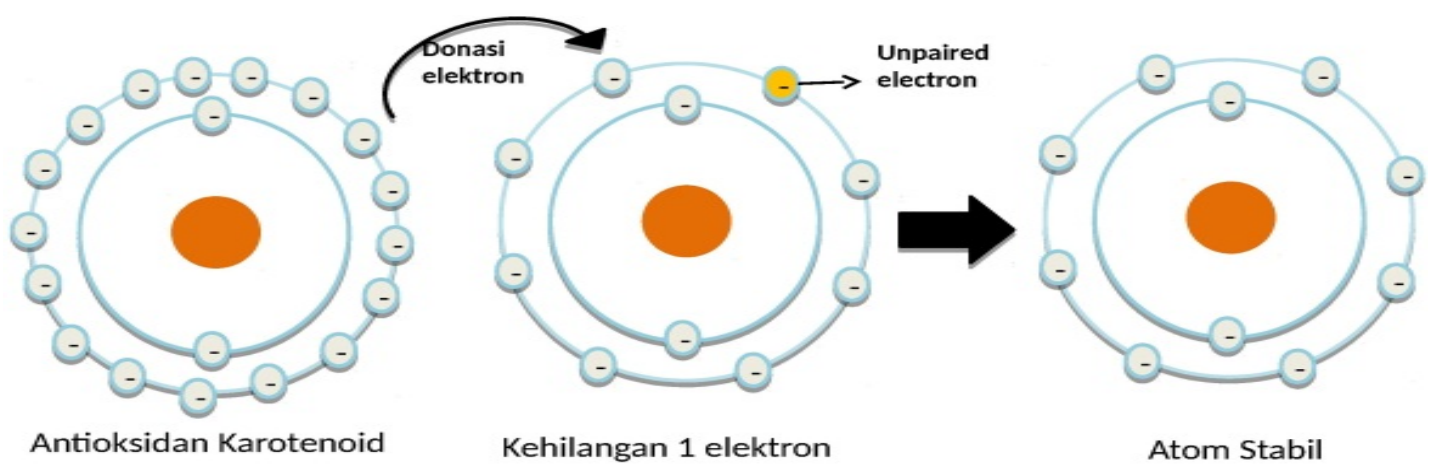

Gambar 1. Mekanisme karotenoid menetralisir radikal bebas

\section{Kesimpulan}

Berdasarkan kajian literature, disimpulkan bahwa karotenoid sangat efisien sebagai peredam fisika dan kimia dari singlet oksigen (102) dan kelompok radikal bebas lainnya serta agen potensial melawan gangguan yang dimediasi radikal bebas.

\section{Ucapan Terima Kasih}

YAL mengucapkan terima kasih kepada Kementerian Pendidikan Nasional yang telah memberikan beasiswa melalui program beasiswa unggulan Dikti tahun 2015 kerja sama Program Magister Biologi, Universitas Kristen Satya Wacana Salatiga.

\section{Daftar Pustaka}

Bahorun T, Soobrattee MA, Luximon-Ramma V, Aruoma Ol. Free radicals and antioxidants in cardiovascular health and disease. Internet J. Med. Update. 2006; 1: 1-17

Christensen, R.L. The Electronic States of Carotenoids. In The Photochemistry of Carotenoids; Frank, H.A., Young, A.J., Britton, G., Eds.; Kluwer Academic Publishers: Dordrecht, the Netherlands, 1999; pp. 137-157

Devasagayam, T.P.A.; Tilak, J.C.; Boloor, K.K.; Sane, K.S.; Ghaskadbi, S.S.; Lele, R.D. Free Radicals and Antioxidants in Human Health: Current Status and Future Prospects. J. Assoc. Phys. India 2004, 52, 794-804

Droge W. Free radicals in the physiological control of cell function. Review. Physiol. Rev. 2002; 82: 47-95. 
Edge, R.; Truscott, T.G. Properties of Carotenoid Radicals and Excited States and Their Potential Role in Biological Systems. In Carotenoids: Physical, Chemical, and Biological Functions and Properties; Landrum, J.T., Ed.; CRC Press: Boca Raton, FL, USA, 2010; pp. 283-308.

El-Agamey, A.; Lowe, G.M.; McGarvey, D.J.; Mortensen, A.; Philip, D.M.; Truscott, T.G.; Young, A.J. Carotenoid radical chemistry and antioxidant/pro-oxidant properties. Arch. Biochem.

Biophys. 2004, 430, 37-48.

Fiedor, J.; Fiedor, L.; Kammhuber, N.; Scherz, A.; Scheer, H. Photodynamics of the bacteriochlorophyll-carotenoid system. 2. Influence of central metal, solvent and $\beta$-carotene on photobleaching of bacteriochlorophyll derivatives. Photochem. Photobiol. 2002, 76, 145-152.

Fiedor, J.; Fiedor, L.; Winkler, J.; Scherz, A.; Scheer, H. Photodynamics of the bacteriochlorophyll-carotenoid system. 1. Bacteriochlorophyll-photosensitized oxygenation of $\beta$ carotene in acetone. Photochem. Photobiol. 2001,74, 64-71.

Gross, J. Pigmen in Vegetables. Van Nastrand Reinhold. New York. 1991.

Halliwell B, Gutteridge JMC. Free radicals in biology and medicine. 4th ed. Oxford, UK: Clarendon Press. 2007

Husain, S.R.; Cillard, J.; Cillard, P. Hydroxyl radical scavenging activity of flavonoids.

Phytochemistry 1987, 26, 126-133

Pham-Huy et al, Free Radicals, Antioxidants in Disease and Health. International journal of Biomedical science, Int J Biomed Sci 2008; 4 (2): 89-96.

Rada, B.; Leto, T.L. Oxidative innate immune defenses by Nox/Duox family NADPH oxidases. Contrib. Microbiol. 2008, 15, 164-187

Richter, C.; Park, J.W.; Ames, B.N. Normal oxidative damage to mitochondrial and nuclearDNA is extensive. Proc. Natl. Acad. Sci. USA 1988, 85, 6465-6467.

Scheer, H. The Pigments. In Light-Harvesting Antennas in Photosynthesis; Green, B.R., Parson, W.W., Eds.; Kluwer Academic Publishers: Dordrecht, the Netherlands, 2003; pp. 29-81.

Stadtman, E.R.; Levine, R.L. Protein oxidation. Ann. N. Y. Acad. Sci. USA 2000, 90, 191-208.

Stahl, W., Sies, H. 2003. Antioxidant Activity of Carotenoids. Molecular Asfects of Medicine. 24, 345-351.

University Of California. The three phases of radical chain reactions.. Online :https://chem.libretexts.org/Textbook Maps/Organic Chemistry Textbook Maps/Map\%3A Orga nic Chemistry with a Biological Emphasis (Soderberg)/17\%3A Radical reactions/17.2\%3A R adical chain reactions. 2014.17.2A(di akses 1 Juli 2017)

Valko M, Izakovic M , Mazur M, Rhodes CJ, et al. Role of oxygen radicals in DNA damage and cancerincidence. Mol. Cell Biochem. 2004;266: 37-56

Valko M, Leibfritz D, Moncola J, Cronin MD, et al. Free radicals and antioxidants in normal physiological functions and human disease. Review. Int. J. Biochem. Cell Biol. 2007; 39: 44 